\title{
Transforming Schools: The Power of Teachers' Input in Professional Development
}

\author{
Linda E. Martin \\ Ball State University \\ Sherry Kragler \\ Winter Park, Florida \\ Diana Quatroche \\ Indiana State University \\ Kathryn Bauserman \\ Indiana State University
}

\begin{abstract}
Recent legislative actions have mandated the professional development of teachers in hopes of improved student achievement. However, research has shown that mandated professional development most usually does not lead to a positive outcome. This article describes three aspects that have been identified as contributing to the transformation of instruction in schools: school context, role of the administrator, and cohesion between professional development and needs of students/teachers. Mezirow's adult learning theory supports these important aspects of school reform and has implications for planning and developing educators' professional development.
\end{abstract}

Keywords: teacher reflection; school transformation; professional development

\section{Introduction}

School reform in the format of mandated policies at various levels (federal, state, and local) is a continual pattern as educators (administrators and teachers) attempt to solve issues that impede student achievement. Generally, students' achievement scores (from kindergarten through high school) have been the focus of most mandates for decades (Long, 2014), through rethinking and reshaping teachers' instructional practices. However, research has shown that changing instructional practices is not an easy task (Kragler, Martin, \& Sylvester, 2014) and takes time as teachers reflect on the outcome of their practices. Research on this topic, commonly known as teacher professional development, captures what is known about how teachers make changes in their practices that can ultimately lead to students' success and the transformation of teachers' beliefs and instructional practices over time. To understand how educators transform practices that lead to student achievement, we examined more closely how adults—and, in this case, educatorsdevelop professionally and how this can lead to a transformation of the instructional beliefs and practices in schools. This aligns with Mezirow's (1995) transformational learning theory, where he describes how adults make changes in their behavior. His theory has implications for educators as they face new professional challenges and modifications in their classroom instruction.

Mezirow (2003) defined transformative learning as "learning that transforms problematic frames of reference-sets of fixed assumptions and expectations (habits of mind, meaning perspectives, mindsets)-to make them more inclusive, discriminating, open, reflective, and emotionally able to 
change" (p. 58). According to Mezirow (1997), adults generally think and act according to a set of values and experiences. In addition, adults accumulated world knowledge become frames of reference to help them understand, shape, and interpret their various experiences, perceptions, and feelings.

Further, Mezirow (2003) believed that transformation always begins with a problem or conflict that is not aligned with our frames of reference or is inconsistent with some aspect of our belief system, "We have a strong tendency to reject ideas that fail to fit our preconceptions, labeling those ideas as unworthy of consideration-aberrations, nonsense, irrelevant, weird, or mistaken" (p. 5). But he also noted, "When circumstances permit, transformative learners move toward a frame of reference that is more inclusive, discriminating, self-reflective, and integrative of experience" (p. 5). Once this happens, individuals can examine their beliefs, can rethink their stance, and can begin to think of how changes can take place.

Within this social constructive theoretical model, Mezirow (1995) identified three general areas that illuminate how adults transform their learning. These three general areas have been paraphrased.

(1) Adults examine their beliefs and experiences. As teachers are introduced with new instructional practices, they reflect on what they believe about affective teaching and how this new practice fits within that frame.

(2) Adults use critical reflective assessment either individually or with peers. As teachers reflect individually and/or with their peers about their assumptions and beliefs of what is included in effective instructional practices, often the discourse is a struggle as they are individually challenged to incorporate new and different innovations into their beliefs and their instruction.

(3) Reflective rational discourse leads adults to take action and a transformation of beliefs and behaviors.

Ultimately, teachers are more apt to continue to reflect and to examine new methods of instructional practices that will change their instructional practices and their personal belief systems over time if their students are learning (Desimone \& Stuckey, 2014). This does not happen quickly, but over time and with practice.

In essence, professional development of teachers and administrators require them at times to change their personal belief systems and their teaching repertoires. Therefore, school systems could consider Mezirow's transformative theory as a guide to reflect on the needs of educators in their schools and develop a professional development plan that will lead schools to success. The scenario that follows represents a Midwestern school district and the types of decisions the district level made to help increase test scores of students enrolled in a failing school. As can be seen, it is difficult for change to occur in schools.

\section{Oak Street Elementary}

Oak Street Elementary School is a failing Title I school that serves a high-poverty neighborhood of prekindergarten to fifth-grade students. Professional development initiatives are top-down from the school district's central office. Because of the way professional development is implemented, every classroom is expected to implement or incorporate what is being promoted at the district level. There is not much teacher input as to professional development topics based on the individual needs of the schools. For example, Ms. Smith (pseudonym) is expected to post a chart emphasizing the six traits of writing. The scripted Everyday Math Program is mandatory. In the case of reading instruction other than sharing assessment scores with the classroom teachers, there is not a plan to use the 
results of the assessments to differentiate instruction. Teachers at Oak Street are not involved in the kinds of professional development that are specific to the needs of their school. They often do not fully understand how the professional development will impact their instruction. Because of this lack of cohesion and alignment between professional development and perceived needs, transformation does not happen. After 10 years being labeled as a failing school, they are still a failing school. In the 10 years of failure, four principals have assumed leadership roles in the school. Each principal has had a different management style, leaving the teachers confused.

In the case of Oak Street Elementary, the principal is in charge of implementing professional development that was initiated at the district level. In spite of different school populations and contexts, all elementary schools across the district are expected to apply their professional development in the same way. This makes it difficult for Oak Street Elementary to transform from a failing school to a Blue Ribbon School. As a result, the teachers lack ownership in the professional development process, as it has not been tailored to meet the needs of their student population. Therefore, they have not had a voice in the professional development curriculum. It would be beneficial if the educators at Oak Street could examine the literature that demonstrates successful professional development efforts can help to transform schools into learning communities for all: teachers, administrators, and students.

\section{Discussion}

Several different issues emerge from the example of Oak Street Elementary School that may negatively impact the transformation of educators' beliefs and instructional practices, for example, school context, definition of roles, cohesion, and alignment. Current professional development policies at Oak Street Elementary do not necessarily take into account differences in school context. For example, schools in urban settings, rural settings or suburban settings may have different economic levels and student populations, may have different beliefs about education, and may have different levels of community support. Consequently, a district could have schools with $90 \%$ of their students who are disadvantaged where other schools may not.

Professional development programs that consider a school's context are more successful (Boatright, Miels, \& Hendricks, 2014; Montgomery, 2014; Myers, 2014). Principals and school leaders who have achieved success have allowed teachers to have a voice, take control, or lead professional development that is meaningful to their school context (Boatright et al., 2014; Donlan, 2014; Hudak, 2014). Based on best practices, school leaders organize professional development in such a way that builds on recognized needs, mission, or goals of the school and meets the learning needs of the students in this particular context (Donlan, 2014; Morewood, 2014; Simons, McClure, \& Hampson, 2014). Ultimately, successful professional development has the goal of transforming beliefs and practices. These particular examples demonstrate the power of transformation on improved student learning (Griffith, Plummer, Connery, Conway, \& Wade, 2014; Hudak, 2014; Myers, 2014). Within this context, there are three important issues that are often never considered: (a) understanding the school context, (b) defining the role of the school administrator, and (c) providing cohesive and aligned professional development to meet educators' instructional needs in order to meet students' learning. All of this should be nested within a frame that transforms teachers' and administrators' beliefs and practices. These three areas are discussed in more detail.

\section{Understanding the School Context}

The context of school sets the stage for how successfully teachers will be able to guide their students' learning and is a critical factor in school reform. The school context includes the composition of a schools' population (students, teachers, administrators, and community that supports the school), the educational practices and management that lead to learning, and the content for learning 
(Opkenakker \& Van Damme, 2007). The school context is also shaped by a variety of other aspects, such as (a) the school's established routines and traditions, (b) the teachers' collegial relationships, (c) the space and time for teachers to learn, and others. Sarason (1996) asserted that all schools are unique because of the people who inhabit them and that learning for students cannot happen if the culture does not support the learning of teachers and other school personnel.

Further, teachers bring different professional needs, experiences, and interests to the classroom and are at different stages of professional learning (Crafton \& Kaiser, 2011). For example, some teachers may be just learning how to teach writing, whereas others are becoming teacher leaders and are ready to model effective writing instruction. This in turn allows teachers to respond to professional development differently depending on their instructional philosophies and the strategies they believe are successful. Within this context, teachers need to have choices for how to teach the students the expected skills (Coburn, 2006).

In addition, students bring different needs, experiences, interests, motivation, sociocultural perspectives, and developmental stages to the classroom (Enciso \& Lewis, 2001). Considering the different attributes that educators and their students bring to a learning environment, Taylor (2009) believed one has to consider the context in which transformative learning will take place and that includes an

appreciation and understanding of the personal and socio-cultural factors that play an influencing role in the process of transformative learning ... such as the surroundings of the immediate learning event, the personal and professional situation of the learners at the time, and the background context that is shaping society (p. 11)

and, in this case, the school and school community. Due to the various policies and mandates in today's schools, it is increasingly difficult for school administrators to create an environment where teachers' voices are heard and students' learning needs are met.

\section{Defining the Role of the School Administrator}

As was demonstrated previously, the context of a school culture includes those in leadership positions within the school, and most often, the school administrator (Bryk, Sebring, Allensworth, Luppescu, \& Easton, 2010). The school administrator sets the tone for how school faculty will work together to develop a positive learning environment for students as well as the teachers (Leithwood, Harris, \& Hopkins, 2008). In effective schools, the working atmosphere is collaborative where teachers and staff are valuable participants in the decision-making process, which may include a distribution of shared responsibility and a shared school vision for improvement that is sustainable over time. A valued part of this process should be time for the teachers and administrators to reflect on what is learned, to conduct inquiry to further understand, and to implement new practices as they are learning (Vandeweghe \& Varney, 2006). Bandura (2000) believes that a sense of collective efficacy can be achieved by adults working together to solve problems which in turn can lead to shared beliefs and a willingness to act collectively. In order to accomplish this, the administrator needs to set the tone for effective collaboration while understanding that issues may arise as risks are taken (Darling-Hammond \& Richardson, 2009). Consequently, educators who work together to address the issues that surround any transformation of beliefs, learning, and practice create an atmosphere of unity and is a powerful tool for school reform.

Finally, school reform will not happen without the support of the district office administrators (Tallerico, 2014). Therefore, the school administrator must work closely with the district office administrators to initiate support for any new schoolwide plan. This spirit of cooperation and support gives the school administrator the autonomy to work for the best interest of the teachers and their students. This is especially important when it comes to any state and federal initiatives that 
filter down to the school districts and then to schools. Even though school districts cannot ignore state and federal initiatives, the individual school administrators, with support from the school district, should act as gatekeepers with any new initiative to make sure that the individual needs of the teachers and students in their school community are supported. Adjustments to mandates and initiatives should be made based on students' needs.

\section{Providing Cohesive and Aligned Professional Development to Meet Students' Needs}

There needs to be alignment between federal/state and school expectations for the delivery of teachers' instructional methods that result in meaningful content for students. Even so, often, policy makers understand alignment differently than school administrators and classroom teachers, and it also differs across the regions of a state (Honig, 2006). In addition, Coburn (2006) found that teachers respond to professional development differently depending on their instructional philosophies and the strategies they believe are successful. Transformative learning can only take place when teachers are given the opportunity to examine new ideas and content in conjunction with their own beliefs and expectations (Mezirow, 2009). Within this problem-solving frame, teachers should be given choices of how to approach the instruction of any new skills and content within their classrooms (Knowles, 1980).

According to Darling-Hammond, Wei, Andree, Richardson, and Orphanos (2009), when professional development aligns with local school improvement efforts, there is greater impact on classroom practices because of the cohesive nature of their professional development activities. When there is a disconnect between local or state initiatives and professional development, the impact on practice is diminished or can even be negative. In the case of Oak Street Elementary, the district does not seek teacher input into professional development or consider how mandates could best be implemented in the various district schools. The outcome will be professional development as a top-down model, which teachers do not necessarily embrace. This leads to a school environment that is disconnected and lacks cohesion. To a greater extent, the impact of professional development can be negative if practices and activities are inconsistent with the professional growth needs of the teachers to make needed changes. Considering whole-school reform at Oak Street Elementary, the educators must think about the context of the school, the expectations of the administrator, and the ease of the alignment of new beliefs as well as the transition of new practices into the classrooms. Consequently, the educators (teachers and administrators) are critical to any transformation within the school.

\section{Transformation to a Learning Environment for All}

The issue facing the schools in the Oak Street district is the low test scores of their students. Because of this, the district mandated certain programs, and the principal was in charge of implementing professional development that was initiated at the district level. However, the teachers and school administrator were not involved in decisions regarding their old or new prescribed instructional practices. For transformation to occur, action needs to be taken, teacher beliefs regarding their instruction need to be examined, and teachers need the opportunity to reflect and collaborate about their instructional practices.. These are recursive, ongoing actions. As Cochran-Smith (2011) pointed out, "learning to teach never ends" (p. 22).

\section{Taking Action}

To facilitate the transformation of the school context, Desimone and Stuckey (2014) found that incorporating more holistic approaches unifies and aligns the different aspects of professional development. For this to take place, educators must be able to think about any new program that enters their school and how to incorporate it into the classroom practices. As the teachers and administers collaborate and reflect on their school, they should focus their reform initiatives on the school's needs and concerns (Ross, 2010) rather than on a goal that would be difficult to achieve (e.g., 
having all children read at grade level by third grade). Given the uniqueness of each school culture, this ensures the alignment of various policies with teachers' understanding of the relationship of the policies with the standards and the curriculum materials they are expected to teach.

The transformation of one's beliefs and practices begins when "individuals become a more autonomous thinkers by learning to negotiate his or her own values, meanings, and purpose rather than uncritically acting on those of others" (Mezirow, 1997, p. 11). This only happens when teachers and administrator work together as a cohesive team to plan the professional development that is needed. Doing so allows the teachers and administrators at Oak Street the opportunity to find "context-based solutions" (Woodside-Jiron \& Gehsmann, 2009, p. 66) for their school. Thus, teachers need the autonomy to examine their individualized instructional concerns to support their specific professional learning (Snow, Griffin, \& Burns, 2005).

\section{Examining Teacher Beliefs Regarding Their Instruction}

According to Mezirow (1997), adults' examination of their beliefs and assumptions when introduced to new ideas is essential. As seen at Oak Street Elementary, there has been no time for reflection and dialogue to work through the educators' discomfort of any new project in a nonthreatening environment (Brookfield, 2000; Servage; 2008). Change will not happen unless teachers have the opportunity to work through the issues that they may encounter when introduced to new practices that do not align with their beliefs about how their students learn best. Considering this, Guskey $(2003,2014)$ pointed out that teachers need the opportunity to try out new practices while examining the success of their students-they are more apt to support new practices that lead to their students' success.

\section{Discourse, Reflection, and Dissonance}

As teachers and administrators begin to reflect on their beliefs and instructional practices, it should be recognized that dissent is a natural part of these conversations (Hargreaves, 2004). It helps that, as Servage (2008) suggested, any beginning conversations be open-ended and centered around "foundational" educational concerns rather than immediate issues, such as the focus on data. As teachers are reflecting on new initiatives that may impact their classroom practices, it is important that they share their individual interpretations of the professional development.

Further, administrators must understand that professional learning that leads to transformation, whether chosen or mandated, is messy, and dissonance can occur as educators are required to go out of their comfort zone and confront their belief systems to make any changes (Festinger, 1957; Wheatley, 2002). First attempts to use a new practice may not go smoothly. In fact, educators may question their abilities and revert back to what is comfortable if not given the opportunity to reflect on what is learned and how to apply it (Coburn, 2001, 2006; Spillane, Reiser, \& Reimer, 2002). This process is necessary for the transformation of beliefs and practices to occur (Donnelly et al., 2005).

\section{Conclusion}

Teachers are the focus of any reform effort and most federal/state initiatives. Thus, teachers appear to be the objects of professional development policies as well as the method for change desired by policy makers (Valencia \& Wixon, 2004). In reality, though, teachers are only one aspect of the school-learning environment. The policies and initiatives at the federal, state, and district levels can either help teachers in the transformation of their classroom practices or set up road blocks for teacher transformation that could negatively impact student learning. Teachers are part of a school culture, and the goal should be the transformation of the whole school environment as well as the individual educator to support positive student outcomes (Sarason, 1996, 2004). 


\section{References}

Bandura, A. (2000). Exercise of human agency through collective efficacy. Current Directions in Psychological Science, 9, 75-78.

Boatright, K., Miels, J., \& Hendricks, M. (2014). Rhoades Elementary and Ball State University working together to impact student learning. In L. E. Martin, S. Kragler, D. J. Quatroche, \& K. L Bauserman (Eds.), Handbook of professional development in education: Successful models and practices, PreK-12 (pp. 509-512). New York, NY: Guilford Press.

Brookfield, S. (2000). Transformative learning as ideology critique. In J. Mezirow \& Associates (Eds.), Learning as transformation: Critical perspectives on a theory in progress (pp. 125148). San Francisco, CA: Jossey-Bass.

Bryk, A., Sebring, P., Allensworth, P., Luppescu, S., \& Easton, J. (2010). Organizing schools for improvement: Lessons from Chicago. Chicago, IL: University of Chicago Press.

Coburn, C. E. (2001). Collective sense making about reading: How teachers mediate reading policy in their professional communities. Educational Evaluation and Policy Analysis, 23, 145-170.

Coburn, C. (2006). Framing the problem of reading instruction: Using frame analysis to uncover the microprocesses of policy implementation. American Educational Research Journal, 43, 343379.

Cochran-Smith, M. (2011). Does learning to teach ever end? Kappa Delta Pi Record, 47, 22-24. doi:10.1080/002289858.2011.1051719.

Crafton, L., \& Kaiser, E. (2011). The language of collaboration: Dialogue and identity in teacher professional development. Improving Schools, 14, 104-116.

Darling-Hammond, L., \& Richardson, N. (2009). Teacher learning: What matters? Educational Leadership, 66, 46-53.

Darling-Hammond, L., Wei, R. C., Andree, A., Richardson, N., \& Orphanos, S. (2009). Professional learning in the learning profession: A status report on teacher development in the United States and abroad. Dallas, TX: National Staff Development Council. Retrieved from http://www.learningforward.org/docs/pdf/nsdcstudy2009.pdf

Desimone, L. M., \& Stuckey, D. (2014). Sustaining teacher professional development. In L. E. Martin, S. Kragler, D. J. Quatroche, \& K. L Bauserman (Eds.), Handbook of professional development in education: Successful models and practices, PreK-12 (pp. 467-482). New York, NY: Guilford Press.

Donlan, R. (2014). Professional development at Bay-Arenac Community High School, Michigan. In L. E. Martin, S. Kragler, D. J. Quatroche, \& K. L Bauserman (Eds.), Handbook of professional development in education: Successful models and practices, PreK-12 (pp. 512-515). New York, NY: Guilford Press.

Donnelly, A., Morgan, D., DeFord, D., Files, J., Long, S., Mills, H., \& Styslinger, M. (2005). Transformative professional development: Negotiating knowledge with an inquiry stance. Language Arts, 82, 336-346.

Enciso, P., \& Lewis, C. (2001). This issue. Theory Into Practice, 40, 146-149.

Festinger, L. (1957). The theory of cognitive dissonance theory approach. White Plains, NY: Row, Peterson and Company.

Griffith, P., Plummer, A., Connery, L., Conway, S., \& Wade, D. (2014). Successful staff development transforms writing instruction in an Oklahoma school. In L. E. Martin, S. Kragler, D. J. 
Quatroche, \& K. L Bauserman (Eds.), Handbook of professional development in education: Successful models and practices, PreK-12 (pp. 521-527). New York, NY: Guilford Press.

Guskey, T. (2003). What makes professional development effective? Phi Delta Kappan, 84, 740-748.

Guskey, T. (2014). Measuring the effectiveness of educators' professional development. In L. E. Martin, S. Kragler, D. J. Quatroche, \& K. L Bauserman (Eds.), Handbook of professional development in education: Successful models and practices, PreK-12 (pp. 447-466). New York, NY: Guilford Press.

Hargreaves, A. (2004). Teaching in the knowledge society: Education in the age of insecurity. New York, NY: Teachers College Press.

Honig, M. I. (2006). Complexity and policy implementation: Challenges and opportunities for the field. In M. I. Honig (Ed.), New directions in education policy implementation: Confronting complexity (pp. 1-23). Albany, NY: SUNY Press.

Hudak, M. (2014). Professional development at Candeo Peoria, Arizona. In L. E. Martin, S. Kragler, D. J. Quatroche, \& K. L Bauserman (Eds.), Handbook of professional development in education: Successful models and practices, PreK-12 (pp. 527-530). New York, NY: Guilford Press.

Knowles, M. (1980). The modern practice of adult education: From pedagogy to andragogy (2nd ed.). New York, NY: Cambridge Books.

Kragler, S., Martin, L., \& Sylvester, R. (2014). Lessons learned: What our history and research tell us about teachers' professional learning. In L. E. Martin, S. Kragler, D. J. Quatroche, \& K. L Bauserman (Eds.), Handbook of professional development in education: Successful models and practices, PreK-12 (pp. 483-505). New York, NY: Guilford Press.

Leithwood, K., Harris, A., \& Hopkins, D. (2008). Seven strong claims about successful school leadership. School Leadership and Management, 28, 27-42.

Long, R. (2014). Federal investments in professional development: What do 50 years of experience tell us about what it takes to make a difference. In L. E. Martin, S. Kragler, D. J. Quatroche, \& K. L Bauserman (Eds.), Handbook of professional development in education: Successful models and practices, PreK-12 (pp. 22-41). New York, NY: Guilford Press.

Mezirow, J. (1995). Transformation theory of adult learning. In M. R. Welton (Ed.), In defense of the lifeworld (pp. 39-70). New York, NY: SUNY Press.

Mezirow, J. (1997). Transformative learning: Theory to practice. New Directions for Adult and Continuing Education, 1997, 5-12.

Mezirow, J. (2003). Transformative learning and discourse. Journal of Transformative Education, 1, $58-63$.

Mezirow, J. (2009). Transforming learning theory. In J. Mezirow, E. Taylor, and Associates (Eds.), Transformative learning in practice: Insights from community, workplace, and higher education (pp. 18-31). San Francisco, CA: Wiley and Sons.

Montgomery, J. (2014). Professional development at Peachtree Preschool, Georgia. In L. E. Martin, S. Kragler, D. J. Quatroche, \& K. L Bauserman (Eds.), Handbook of professional development in education: Successful models and practices, PreK-12 (pp. 531-534). New York, NY: Guilford Press.

Morewood, A. (2014). Supporting teacher researchers in a rural prek-5 school, West Virginia. In L. E. Martin, S. Kragler, D. J. Quatroche, \& K. L Bauserman (Eds.), Handbook of professional development in education: Successful models and practices, PreK-12 (pp. 518-521). New York, NY: Guilford Press 
Myers, N. (2014). Professional development at Schaumburg School District 54, Illinois. In L. E. Martin, S. Kragler, D. J. Quatroche, \& K. L Bauserman (Eds.), Handbook of professional development in education: Successful models and practices, PreK-12 (pp. 515-518). New York, NY: Guilford Press

Opkenakker, M., \& Van Damme, J. (2007). Do school context, student composition and school leadership affect school practice and outcomes in secondary education? British Educational Research Journal, 33, 179-206.

Ross, C. (2010, December). Changing your school? First, work on the culture. Retrieved from ERIC database. (ED 537415)

Sarason, S. (1996). Revisiting the culture of school and the problem of change. Boston, MA: Allyn \& Bacon.

Sarason, S. (2004). And what do you mean by learning? Portsmouth, NH: Heinemann.

Servage, L. (2008). Critical and transformative practices in professional learning communities. Teacher Education Quarterly, 35, 63-77.

Simons, B., McClure, D., \& Hampson, I. (2014). Professional Learning at The Hamilton and Alexandra College, Australia. In L. E. Martin, S. Kragler, D. J. Quatroche, \& K. L Bauserman (Eds.), Handbook of professional development in education: Successful models and practices, PreK-12 (pp. 534-539). New York, NY: Guilford Press.

Snow, C., Griffin, P., \& Burns, M. (Eds.). (2005). Knowledge to support the teaching of reading. San Francisco, CA: John Wiley \& Sons.

Spillane, J., Reiser, B., \& Reimer, T. (2002). Policy implementation and cognition: Reframing and refocusing implementation research. Review of Educational Research, 72, 387-431.

Tallerico, M. (2014). District issues: Administrators at all levels involved in teachers' professional development. In L. E. Martin, S. Kragler, D. J. Quatroche, \& K. L. Bauserman (Eds.), Handbook of professional development in education: Successful models and practices, PreK-12 (pp. 125-144). New York, NY: Guilford Press.

Taylor, E. W. (2009). Fostering transformative learning. In J. Mezirow, E. Taylor, and Associates (Eds.), Transformative learning in practice: Insights from community, workplace, and higher education (pp. 3-17). San Francisco, CA: Wiley and Sons.

Valencia, S. W., \& Wixson, K. K. (2004). Literacy policy and policy research that makes a difference. In R. B. Ruddell, \& N. J. Unrau (Eds.), Theoretical models and processes of reading (5th ed., pp. 69-92). Newark, DE: International Reading Association.

Vandeweghe, R., \& Varney, K. (2006). The evolution of a school-based study group. Phi Delta Kappan, 88, 282-286.

Wheatley, K. (2002). The potential benefits of teacher efficacy doubts for educational reform. Teaching and Teacher Education, 18, 5-22.

Woodside-Jiron, H., \& Gehsmann, K. (2009). Peeling back the layers of policy and school reform: Revealing the structural and social complexities within. International Journal of Disability Development, and Education, 56, 49-72. 
The Journal of Educational Research and Practice provides a forum for studies and dialogue that allows readers to better develop social change in the field of education and learning. Journal content may focus on educational issues of all ages and in all settings. It also presents peer-reviewed commentaries, book reviews, interviews of prominent individuals, and additional content. The objectives: We publish research and related content that examines current relevant educational issues and processes aimed at presenting readers with knowledge and showing how that knowledge can be used to impact social change in educational or learning environments. Additional content provides an opportunity for scholarly and professional dialogue regarding that content's usefulness in expanding the body of scholarly knowledge and increasing readers' effectiveness as educators. The journal also focuses on facilitating the activities of both researcher-practitioners and practitioner-researchers, providing optimal opportunities for interdisciplinary and collaborative thought through blogging and other communications.

Walden University Publishing: http://www.publishing.waldenu.edu 